\title{
The Constituent Elements of Leadership at Basic Level Organizations: An Exploratory Research Based on Grounded Theory
}

\author{
Lei LEI ${ }^{1, a}$, Yan-Mei XU ${ }^{2, b,{ }^{*}}$ \\ ${ }^{1}$ School of Management, Chinese Academy of Science, Room 212, 6th Building Zhongguancun \\ East Road 80, Haidian District, 100190 Beijing, China. \\ ${ }^{2}$ School of Management, Chinese Academy of Science, Room 213, 7th Building Zhongguancun \\ East Road 80, Haidian District, 100190 Beijing, China \\ a journey0505@163.com, ${ }^{\mathrm{b}}$ xuyanmei@ucas.ac.cn, \\ ${ }^{*}$ Corresponding author
}

Key words: Basic Level Organizations, Leadership, Grounded Theory, Psychological Attribution, Upgrading Path, Intellectual Capital

\begin{abstract}
Upgrading the leadership of the basic levelorganizations is a major issue of new socialist countryside construction. However, the two questions of why they upgrade their leadership initiatively and how to promote them are still lack of profound research. This paper applies grounded theory to study the psychological attribution of the leaders upgrading their leadership and the corresponding upgrading path though in-depth interview. The paper finds that the main category of spiritual dimension and starting point are the psychological attribution to upgrade leadership. Furthermore, in order to get better effectiveness, the working methods of the leaders at basic level need to match their personal qualities. The results can provide important implications for the government to induct the behavior patterns of basic level leaders.
\end{abstract}

\section{Introduction}

We are stepping into a knowled ge economy era. In this era, the human intelligence creation is the core. The possession, distribution, production and consumption of intellectual resources are the main economic activities. Therefore, intellectual capital, such as knowledge and ability are playing an increasingly important role to the survival and development of an organization. Intellectual capital includes invisible knowledge and skills, so human capital has become an important carrier of organization's intellectual capital. The knowledge and skills which processed by the leaders at the basic level organizations in China are curial. Therefore, upgrading the leadership of the basic level organizations is a major issue of new socialist countryside construction.

The paper suggests that upgrading the leadership of the basic level organizations is a dynamic process. By seeking specific objectives, leaders at the basic level organizations and their subordinates work together in the certain organization structure. The process involves wide range qualities of the leaders, not only closely related with their personal qualities and political consciousness, but also with the adequacy of their working methods. Thus, the key issues are why the leaders upgrade their leadership and how to promote them. The first question involves to the psychological attribution. The second question concerns how to effectively guide them. Towards these issues, theorists have not yet improved exposition. By focusing the typical urban fringe-Gaobeidian village ${ }^{(1)}$, the paper explores the structure of leadership at the basic level organizations in China and the strategy of the talent development, which has important theoretical and practical significance to the theory of intellectual and the construction of new socialist countryside. 


\section{Lite rature Review}

Currently, the research on the leadership of basic level organizations is still limited. The paper mainly reviews two parts of empirical and theoretical research.

At the empirical aspect, the research of the basic level organizations is still on preliminary stage. The authors only found two articles currently. The first paper is the "Chinese rural development and village level leadership__ as the vegetable market in X village of Beijing suburban an example" ${ }^{[1]}$. The paper thought the connections between the leaders at the basic level organizations and their superiors can help raise development funds, so the leadership at basic level organizations is "external dependency type". The village-level leaders need to have the role functions of "diplomat" (rich network and the ability of communication), "operator" (operating assets and the ability of expanding the size of village collective economy) and "regulator" (the ability of integrating people). Secondly, by historical tracking the village leaders in different periods, Yunxiang Yan $^{[2]}$ found the role of leaders in basic level organizations is significant decline. In his point of view, village leaders have become a special interest group. In many cases, the actions of leaders at the basic level organizations have contrary to the long-term interests of country. The government is changing from the paternalism to tax with ignoring people's livelihood. In addition, the research methods of current leadership study about Chinese basic level organizations are in miniature research stage with lacking of comparative studies across regions.

At the theoretical aspect, we can learn from the findings of leadership. John Antonakis ${ }^{[3]}$ thought the nature of leadership is the process of interaction between leaders and their subordinates. With the development of economy and society, some new leadership theories emerged which include charismatic leadership ${ }^{[4]}$, transactional leadership ${ }^{[5]}$ and transformational leadership ${ }^{[6]}$, etc.

Based on the two empirical researches and the three leadership theories, the paper devotes to in-depth interview and qualitative research for the category of leadership at Chinese basic level organizations. We primarily analysis the psychological attribution and mechanism behind the leaders' behavior at the basic level organizations, rather than test the significance of relationship between the variables by the statistical analysis method. Further, we explore the influence path of upgrading the leadership at basic level organizations.

\section{Research Method and Data Source}

Since the paper aims to find out the psychological attribution of leaders at basic level organizations, there are almost no mature theoretical assumptions and related research. So we choose the Grounded Theory technology of qualitative research. The Grounded Theory was proposed by Glaser and Strauss in 1967 which is an empirical research method of the bottom- up approach to construct a substantive theory based on empirical data ${ }^{[7]}$. When adopting Grounded Theory, we should follow three steps which are Open Coding (open login), Axial Coding (relation login) and Selective Coding (core-type login). On the process of date analysis, we can develop new substantive theory from comparing between data and between theories by Constant Comparison Analysis ideas.

The authors selected Zhi Fen as case study who is the leader of Gaobeidian village ${ }^{2}$. We got the first-hand information by conducting in-depth interviews with relevant person using open-ended questionnaire. By adopting Theoretical Sampling method, we extracted specific interview subject according to the requirement of analysis framework and conceptual development. Considering the needs of covering all levels of population, we conducted in-depth interviews with Zhi Fen herself, her supervisor, subordinates and colleagues, part of villagers and merchants. We determine the 
number of samples according to principle of Theoretical Saturation which means we take samples until the new sample no longer provides new important information. Ultimately, we choose 12 respondents. The total interview time is 1,272 minutes and the total transcribed words are 283,981 . The respondents' statistics are shown in Table 1.

Table 1 List of Respondents' Statistics

\begin{tabular}{|c|c|c|}
\hline Respondents(coding) & Number(person) & Percentage (\%) \\
\hline The party branch secretary-Zhi Fen(ZF01) & 1 & 8.3 \\
\hline Colleagues(ZF02\03) & 2 & 16.7 \\
\hline Villagers(CIT01\02\03\04) & 4 & 33.3 \\
\hline Merchants(BM01\02) & 2 & 16.7 \\
\hline Supervisor(LD01) & 1 & 8.3 \\
\hline Subordinates (SUB01 \02) & 2 & 16.7 \\
\hline Total & 12 & 100 \\
\hline
\end{tabular}

Before the first appointment with the respondents, we informed the interview subjects to them for asking them to prepare the questions. In the formal interviews, we explained our purpose and content of the interview to them until making ensure they understand our interviews correctly. When interviewed the respondents, the main purposes of us are the perception of them to the village Party branch secretary- Zhi Fen and the characteristics of competency about the leaders at basic level organizations. The followings are our main outline of the interview. (1)What are the 2 to 3 pieces of work which the village Party branch secretary did that you most satisfied in the past two years? Why? (2) What are the 2 to 3 pieces of work which the village Party branch secretary did that you most dissatisfied in the past two years? Why? (3) Which thing she has done that particularly touching you in the ten years that the village Party branch secretary working in Gaobeidian? (4) In your opinion, what ability and quality should be processed in order to competent the village Party branch secretary? Around these issues and the conceptual framework, we took further tracking interviews for insight into the inner psychology of the respondents.

\section{Category Extraction and Model Construction}

\section{Open Coding}

Open Coding is a process of breaking data, giving concept and reassembling them in a new function, which can give any sentence or fragment of the original interview data conceptual label to achieve data conceptualization. We analyzed every word of the original interview data for initial conceptualization when we were coding. Eventually we got a total of 292 original statements and the corresponding initial concept among our interviews. Due to the relatively low level of the initial concept, the huge number and a certain degree of cross, it requires further refining to gather related concepts to achieve concept categorization. We removed the initial concepts which appear less frequency (the frequency is less than twice) when categorization, only retain the concepts which appear more than three. Table 2 is the categories we got.

Table 2 Open Coding Categorization

\begin{tabular}{|c|c|c|}
\hline \multicolumn{3}{|c|}{ Categorization } \\
\hline Enthusiastic & Broad-minded & Pragmatic \\
\hline Solve Problems & Good at dealing with the & Field Investigation \\
\hline
\end{tabular}




\begin{tabular}{|c|c|c|}
\hline & relationship with subordinates & \\
\hline Implementation Capacity & Everything for the People & Advanced Consciousness \\
\hline Working Capacity & Good at Employment & Firm Stand \\
\hline $\begin{array}{c}\text { Good at dealing with the } \\
\text { relationship with leaders }\end{array}$ & Provide Spiritual Support & $\begin{array}{c}\text { Education to Party } \\
\text { Members }\end{array}$ \\
\hline
\end{tabular}

\section{Axial Coding}

The main task of Axial Coding is to develop the main category. The specific approach of it is to develop the nature and dimensions of categories. And then linking together each individual category to find and establish the potential logical connections between categories. We found it is exist that the intrinsic links of different categories which from the Open Coding on conceptual level. According to the relationship and logical order between different categories, we re-classified them and summarized four main categories. Table 3 shows the significance of each main category and the corresponding Open Coding categories.

Table 3 The Main Categories of Axial Coding

\begin{tabular}{|c|c|c|}
\hline $\begin{array}{c}\text { Main } \\
\text { Category }\end{array}$ & Corresponding Category & Category Connotation \\
\hline \multirow{2}{*}{$\begin{array}{l}\text { Spiritual } \\
\text { Dimension }\end{array}$} & Provide Spiritual Support & $\begin{array}{l}\text { Great mental strength and providing spiritual } \\
\text { support to others }\end{array}$ \\
\hline & Firm Stand & A firm political stance \\
\hline $\begin{array}{l}\text { Starting } \\
\text { Point }\end{array}$ & Everything for the People & Everything for the welfare of the people \\
\hline \multirow{6}{*}{$\begin{array}{l}\text { Personal } \\
\text { Qualities }\end{array}$} & Enthusiastic & Helpful, warm and affinity \\
\hline & Broad-minded & Generous and tolerant \\
\hline & Pragmatic & Working hard and down to earth \\
\hline & Advanced Consciousness & $\begin{array}{l}\text { Process better forward thinking and high political } \\
\text { sensitivity }\end{array}$ \\
\hline & Good at Employment & Making good use of talent \\
\hline & Working Capacity & $\begin{array}{c}\text { With coordination, organizational skills and } \\
\text { leadership ability }\end{array}$ \\
\hline \multirow{6}{*}{$\begin{array}{l}\text { Working } \\
\text { Method }\end{array}$} & $\begin{array}{l}\text { Good at dealing with the } \\
\text { relationship with leaders }\end{array}$ & $\begin{array}{l}\text { Ability of appreciating the superior spirit, flexibility } \\
\text { and adaptation }\end{array}$ \\
\hline & Solve Problems & $\begin{array}{l}\text { Process determination and methods to solve } \\
\text { problems } \\
\end{array}$ \\
\hline & $\begin{array}{l}\text { Good at dealing with the } \\
\text { relationship with } \\
\text { subordinates }\end{array}$ & Good at resolving conflicts and establishing prestige \\
\hline & Field Investigation & First-hand information \\
\hline & Implementation Capacity & Proposing program and earnestly implement it \\
\hline & $\begin{array}{c}\text { Education to Party } \\
\text { Members }\end{array}$ & $\begin{array}{c}\text { Emphasis on the education of Party members and } \\
\text { the leading role of them }\end{array}$ \\
\hline
\end{tabular}

\section{Selective Coding}

In the Axial Coding stage, the relations between categories will gradually emerge when the main categories develop. The selective coding further processes the relations between categories 
systematically. It excavates the "Core Category" from the main categories and analyzes the links of main category and other category with the core category. Finally, it describes the phenomenon of the overall behavior with "Story Line". The "Story Line" is a typical structure of relationship. It includes not only the relation between categories, but also a variety of conditions. When finishing the "Story Line", a new theoretical framework is developed. The "Story Line" (typical relational structure) of main category about this paper is shown in Table 4.

Table 4 The Typical Relational Structure of Main Category

\begin{tabular}{|l|c|}
\hline \multicolumn{1}{|c|}{ Typical Relational Structure } & \multicolumn{1}{c|}{ The Meaning of Relational Structure } \\
\hline $\begin{array}{l}\text { Spiritual Dimension } \rightarrow \\
\text { Starting Point }\end{array}$ & $\begin{array}{c}\text { The major psychological attribution about the } \\
\text { leadership enhancement of the basic level organization } \\
\text { is the great spiritual strength and providing spiritual } \\
\text { support for others which promote the starting point of } \\
\text { "everything for the people" internally. }\end{array}$ \\
\hline $\begin{array}{l}\text { Personal Qualities } \rightarrow \text { Working } \\
\text { Method }\end{array}$ & $\begin{array}{l}\text { The personal qualities of the leaders at the basic level } \\
\text { organization determine their working methods. }\end{array}$ \\
\hline $\begin{array}{l}\text { Starting Point } \\
\text { Method }\end{array}$ & $\begin{array}{c}\text { The starting point of "everything for the people" } \\
\text { determines the working methods of the leaders at the } \\
\text { basic level organization. }\end{array}$ \\
\hline $\begin{array}{l}\text { Working Method } \rightarrow \\
\text { Upgrading the leadership of the } \\
\text { basic level organizations }\end{array}$ & $\begin{array}{c}\text { Practical working method can upgrade the leadership } \\
\text { of the basic level organization effectively. }\end{array}$ \\
\hline
\end{tabular}

Based on the typical relational structure above, we define the core category of "psychological attribution of the leadership enhancement and the corresponding upgrading path of the Chinese basic level organization". On this basis, the authors construct a new theoretical framework of the leadership enhancement at the basic level organization, which is called "psychological attribution of the leadership enhancement and the corresponding upgrading path of the Chinese basic level organization". It is shown in Fig. 1. 


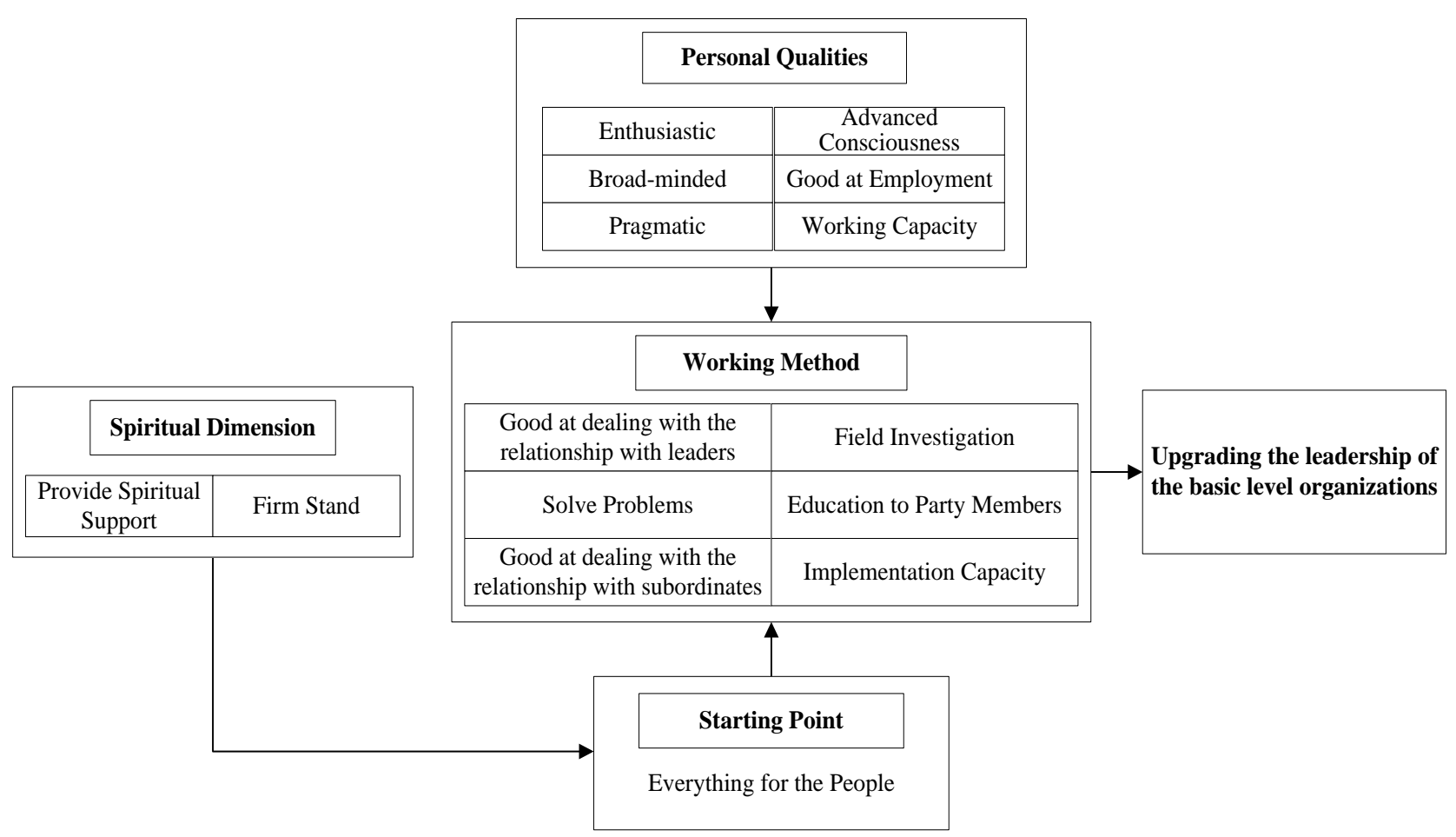

Fig. 1 Psychological Attribution and Upgrading Path

\section{The Model Interpretation and Policy Recommendations}

From the theoretical model of psychological attribution and upgrading path, we can conclude that the spiritual dimension and starting point are the major psychological factors of leadership enhancement on basic level organization. They affect the working method of the basic level leaders. On the other hand, the personal qualities of the basic level leaders can also influence their individual working methods. Their working methods are the visual expression of their level of the leadership. Therefore, the psychological factors, such as spiritual dimension and stating point, working together with the personal qualities influence the working methods of the leaders on basic level organizations. They can enhance their leadership by improving their working methods. This is the leadership upgrading path of Chinese basic level organization. Due to the key of construction on new socialist countryside are people, the leaders of the basic level organization are the most fundamental. Therefore, upgrading the leadership of the basic level organization has great significance to the construction of Chinese new socialist countryside. The paper has two conclusions. (1) Upgrading the leadership of the basic level organization needs a firm political stance and the starting point of everything for the people. It is the basis of the smooth commencement of every work on basic level. (2) The working methods of leaders at basic level organizations should be combined with their personal qualities, which can maximize their effectiveness.

\section{Conclusion and Outlook}

The contributions of the paper are: on the one hand, we conduct exploratory research to the issue of the leadership at basic level organization by qualitative research method. Though interviews with relevant staff, we comprehensively review the categories of the relevant variables which influence the enhancement of organizational leadership by applying Grounded Theory. The leadership is an important constituent element of intellectual capital. Therefore, upgrading the leadership is also the 
essence to the enhancement of intellectual capital, which has practical guidance to the management of basic level organizations. On the other hand, there are so much literature concerning on leadership and rural development. But the research on integrating both of them is rare. The paper integrates the two aspects and constructs an integrated model of the leadership enhancement of Chinese basic level organization. The model explains the psychological attribution and upgrading path of the leadership enhancement at the basic level organization, which is also a supplement of intellectual capital theory. Facing to the evolving needs of society, improving the conversion mechanism between intellectual capital and explicit knowledge of organizations, mobilizing the enthusiasm of the leaders at basic level, and enhancing the management capacity of the basic level organizations are the purpose of enhancing the leadership at basic level organizations. At the same time, they are also the important focuses on attracting and retaining talents working on Chinese basic level organizations.

The paper can provide reference for the government to formulate policies. It can also provide policy ideas and implementation path for the leadership enhancement of basic level organizations. However, the model of the leadership enhancement is constructed by the in-depth interviews and qualitative research of small sample. Its reliability and validity have not been tested by large sample. It need conceptualization to the factors of the model and the development of measurement scale, examining the intrinsic relationship between the variables in the model by a large sample survey.

\section{Notes}

(1) Gaobeidian village locates on the east along the Chang'an Avenue in Beijing. It is only 8 kilometers away from Tiananmen Square. The village is the typical urban fringe. In the process of urbanization, the village has developed to a well-off, civilized and democracy model village from an impoverished one, which set an urban fringe areas model of rapid development.

(2) Since 2002 as the Party branch secretary of Gaobeidian village, Zhi Fen gradually has laid the "three pillars" development pattern of the classical furniture industry, culture arts industry and the pharmaceutical industry with the Party members of the village. In the course of decades in Gaobeidian village, Zhi Fen has been elected as the thirteenth, fourteenth and fifteenth People's Congress deputies. And she has won the honors of the 'National Model Worker", 'National '38' Federation", "National Excellent Party Worker", and "Beijing Outstanding Contributions of Rural Practical Talents", "National Women's Federation Pacesetter", 'National Women Excel Advanced Individual".

\section{Reference}

[1] Yi Wu. Rural China Review (Series 1) [M]. Guangxi: Guangxi Normal University Press, 2006.

[2]Yunxiang Yan. An Anthropologist and His Village [J]. For the Public Good, 2004(17):83.

[3] John Antonakis. The Nature of Leadership [M], London: sage Publications, 2004.

[4] House,R.J.\& Aditya,R.N. The social scientific study of leadership: quo Vadis? [J].Journal of Management, 1997, 23(3):409-473.

[5] Hollander,E.P. Leadership dynamics: A practical guide to effective relationships [M].New York: Free Press, 1978.

[6] Burns,J.M. Leadership[M1. New York: Harper\&Row, 1978.

[7]Xiangming Chen. Qualitative Research in Social Sciences [M].Beijing: Educational Science Press, 2000. 